\title{
Prediksi Potensi Cadangan Air Tanah Menggunakan Persamaan Darcy di Kecamatan Dramaga, Kabupaten Bogor
}

\author{
(Prediction of Groundwater Reserve Potential using Darcy Equation in Dramaga \\ District, Bogor Regency)
}

\author{
Pangestu $^{*}$ dan Roh Santoso Budi Waspodo \\ ${ }^{1,2}$ Departemen Teknik Sipil dan Lingkungan, Fakultas Teknologi Pertanian, Institut Pertanian Bogor. \\ Jl. Raya Dramaga, Kampus IPB Dramaga, PO BOX 220, Bogor, Jawa Barat Indonesia \\ *Penulis korespondensi: pangestu.st@gmail.com
}

Diterima: 15 Agustus 2018

Disetujui: 20 November 2018

\begin{abstract}
Groundwater needs will increase in accordance to area development. Groundwater has a limited quantity because it depends on the geometry and distribution of aquifer. The purpose of this study were to identify soil lithology and aquifer thickness, to determine soil hydraulic conductivity values and to predict potential groundwater reserves in Dramaga District. The processed data were data geoelectric with Schlumberger configuration, hydrogeological maps, and geological maps of Bogor. Aquifer thickness were obtained from the average yield of the aquifer thickness at the research location. Thickness of unconfined aquifer was 14,69 $\mathrm{m}$ and 17,77 $\mathrm{m}$ for confined aquifer. Aquifer had lithological layers of andesite, tuffaceous, sandstone, clay, and sand. The value of hydraulic conductivity was 2,5 $\mathrm{m} /$ day for unconfined aquifer and 2,04 $\mathrm{m} /$ day for confined aquifer. Using the Darcy equation groundwater reserves were estimated 241,29 $\mathrm{m}^{3}$ / day or 2,79 l / s for unconfined aquifers and 1291,19 $\mathrm{m}^{3} /$ day or $14,94 \mathrm{l} / \mathrm{s}$ for confined aquifers.
\end{abstract}

Key words: aquifer, Darcy equation, geoelectric, groundwater reserves

\section{PENDAHULUAN}

Air merupakan sumber daya yang sangat diperlukan oleh makhluk hidup baik untuk memenuhi kebutuhannya maupun menopang hidupnya secara alami. Kegunaan air yang bersifat universal atau menyeluruh dari setiap aspek kehidupan menjadi semakin berharganya air baik jika dilihat dari segi kuantitas maupun kualitasnya. Semakin tinggi taraf kehidupan seseorang, maka kebutuhannya akan air pun akan meningkat (Suriawiria 1996). Air bersih merupakan kebutuhan dasar bagi hajat hidup manusia. Jenis air yang paling aman untuk dikonsumsi manusia adalah airtanah (Mori 2006). Pada umumnya air tanah dimanfaatkan untuk memenuhi keperluan hidup manusia. Hal ini menyebabkan sumberdaya air dapat menjadi barang langka atau barang ekonomi.

Kebutuhan airtanah akan selalu meningkat sesuai dengan perkembangan suatu daerah baik secara fisik maupun sosial, oleh karena itu penelitian yang berkaitan dengan sumber daya airtanah perlu dilakukan secara terpadu dan berkelanjutan. Perlu adanya pengaturan dan pemanfaatan airtanah bagi kebutuhan tersebut sesuai dengan cadangan airtanah yang tersedia (Sudarto 2012). Jika dibandingkan dengan sumber air bersih lainnya, maka airtanah mempunyai nilai ekonomis yang lebih tinggi karena biaya produksi yang rendah dan kualitas lebih baik. Meskipun demikian airtanah mempunyai kuantitas yang terbatas karena tergantung pada geometri dan sebaran akuifernya (Naryanto 2008). Akuifer 
adalah suatu lapisan pembawa airtanah dengan permeabilitas yang cukup untuk mengantarkan dan ditempati oleh airtanah dalam jumlah ekonomis (Azwar 2009).

Cadangan airtanah adalah ketersediaan airtanah yang terdapat di akuifer, dapat disebut sebagai sumber daya tidak terbarukan dalam kasus tertentu bahwa pembaharuan airtanah sangat terbatas, sementara stok persediaannya besar. Itu berarti bahwa akuifer hampir tidak menerima recharge apa pun atau sepenuhnya terisolasi dari sistem yang mengandung sumber daya air terbarukan. Hal itu berarti bahwa waktu pembaharuan cadangan airtanah sangat panjang (Margat dan van der Gun 2013).

Kabupaten Bogor adalah sebuah kabupaten di Provinsi Jawa Barat, Indonesia. kabupaten Bogor merupakan salah satu kota yang saat ini menuju kepada profile metropolitan dimana pertumbuhan pada berbagai sektor menunjukkan kemajuan yang positif. Aktivitas yang terjadi antara lain pembangunan gedung perkantoran, pertokoan, perumahan dan apartemen. Berkaitan dengan adanya pengembangan wilayah terhadap kondisi geologi Kabupaten Bogor, khususnya kondisi hidrogeologi, maka perlu dilakukan suatu kajian hidrogeologi di Kabupaten Bogor yang bisa menjadi referensi berbagai pihak dalam membuat kebijakan, program atau kegiatan pembangunan fisik di kota tersebut. Salah satu kegiatan yang dilakukan adalah melakukan pengkajian potensi cadangan airtanah di Kabupaten Bogor. Salah satu metode yang digunakan adalah dengan menggunakan Hukum Darcy untuk menentukan potensi cadangan airtanah. Airtanah sebagai sumberdaya alam tidak dapat terlihat secara langsung karena terdapat di dalam tanah dan batuan tetapi hampir semua penduduk memanfaatkannya baik untuk keperluan domestik maupun industri (Pratitnyo 2008). Dengan memperhatikan dinamika pertumbuhan pembangunan dewasa ini, maka dipandang perlu untuk melakukan kajian hidrogeologi untuk mengetahui potensi cadangan air tanah di Bogor. Untuk menentukan potensi cadangan air tanah, salah satunya adalah dengan menggunakan geolistrik.

Penelitian yang dilakukan bertujuan untuk: (1) mengidentifikasi litologi lapisan tanah di lokasi penelitian. (2) mengidentifikasi posisi ketebalan akuifer dan menentukan nilai konduktivitas hidrolik tanah di lokasi penelitian dan (3) memprediksi potensi cadangan ketersediaan airtanah di Kecamatan Dramaga, Kabupaten Bogor.

\section{METODOLOGI}

Penelitian dilakukan di Kecamatan Dramaga, Kabupaten Bogor, Jawa Barat. Gambar 1 merupakan peta Kecamatan Dramaga.

Perlengkapan yang diperlukan terdiri atas :Geolistrik Earth Resitivity meter type SAZ 3000 G100, seperangkat komputer beserta perlengkapannya berupa software Progress Version 3.0, GIS 10.0, Surfer 10.0., kabel sepanjang $500 \mathrm{~m}$ sebanyak empat unit untuk elektroda arus, kabel sepanjang $300 \mathrm{~m}$ sebanyak empat unit untuk elektroda potensial, elektoda arus sebanyak dua unit elektroda arus dan dua elektroda potensial, palu sebanyak empat unit untuk menancapkan elektroda ke tanah, AVO meter empat unit, alat komunikasi sebanyak 3 unit dan GPS. Bahan yang digunakan pada penelitian ini antara lain peta topografi, geologi, hidrogeologi, dan peta rupabumi. 


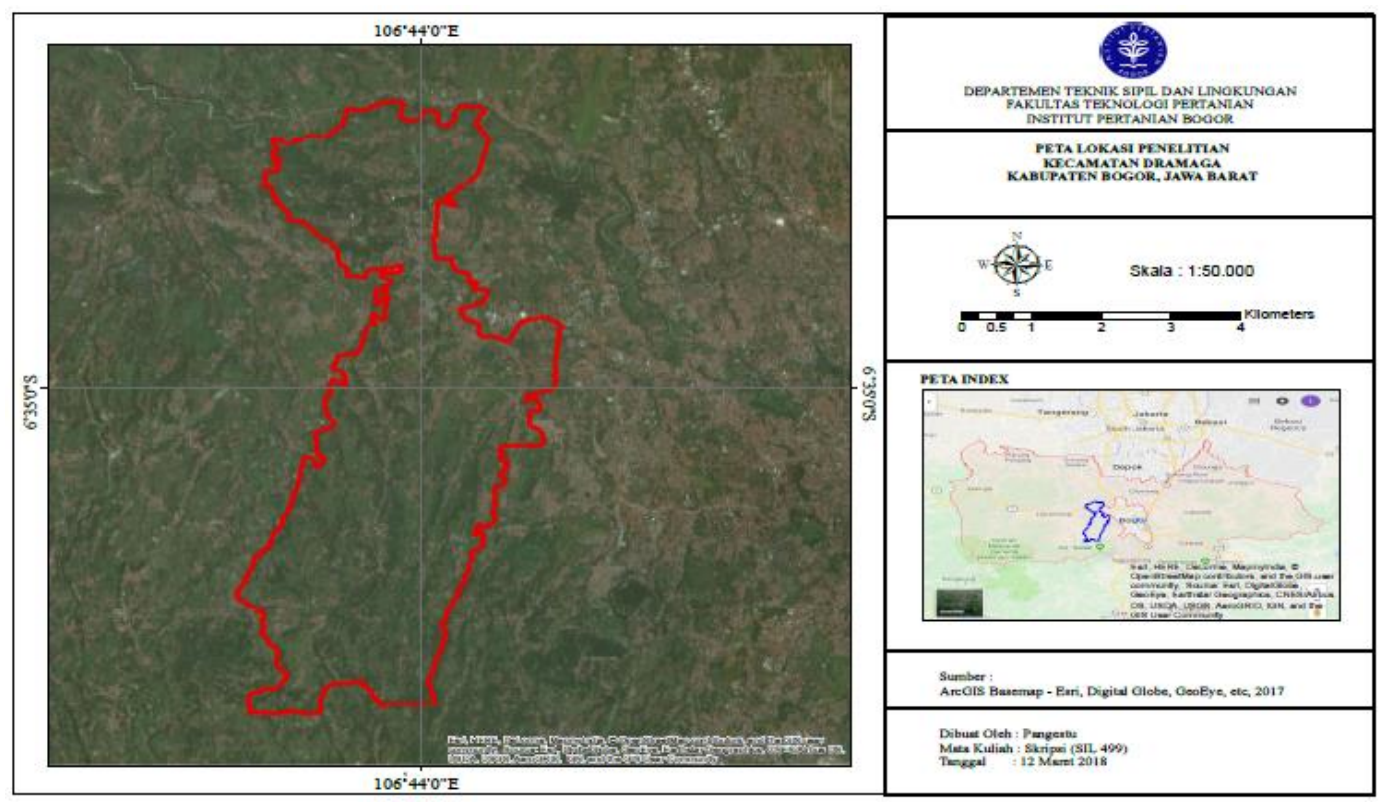

Gambar 1 Lokasi Penelitian

Penelitian dilaksanakan dalam titik penelitian. Pengolahan data primer beberapa tahapan. Tahapan yang dan data sekunder dilakukan untuk dilakukan terdiri atas tahapan memperoleh data gambaran sebaran pengumpulan data, pengolahan data, dan akuifer. Data resistivitas diperoleh dengan analisis data.

Pengumpulan data sekunder umumnya berupa peta-peta yang dibutuhkan. Peta topografi, geologi, hidrogeologi, dan peta Kecamatan Dramaga overlay dengan peta geologi sehingga dapat diketahui batas kecamatan secara geologi, hidrogeologi. Selain itu digunakan juga data-data dari kajian borelog yang sudah ada.

Pengumpulan data primer merupakan data pengukuran geolistrik dengan seperangkat perlengkapannya, data geolistrik berupa borelog Kecamatan Dramaga, kurva vertical electrical sounding (VES), serta nilai resistivitas. Borelog Kecamatan Dramaga berisi data litologi lapisan tanah yang dapat digunakan dalam mengetahui keberadaan akuifer pada suatu lapisan tanah dan dapat mengetahui ketebalan akuifer pada tiap menggunakan software Progress. Garis aliran diolah dengan bantuan Microsoft Excel dan Surfer version 01. Pengolahan data pada software Microsoft Excel berupa data elevasi serta data koordinat pada setiap titik penelitian. Elevasi dan koordinat didapat dari bantuan GPS. Garis aliran (flownet) ditampilkan selanjutnya lapisan akuifer ditentukan dan kemudian data kedalaman akuifer dan ketebalan akuifer pada lokasi penelitian dapat ditentukan. Penampang akuifer perlu ditentukan untuk mengetahui nilai $\mathrm{W}$ dan $\delta \mathrm{L}$ pada hukum darcy. Gambar 2 merupakan titik lokasi pengukuran geolistrik. Titik pengukuran yang dilakukan sebanyak 10 titik untuk menentukan ketebalan akuifer yang mewakili kondisi hidrogeologi Kecamatan Dramaga. 


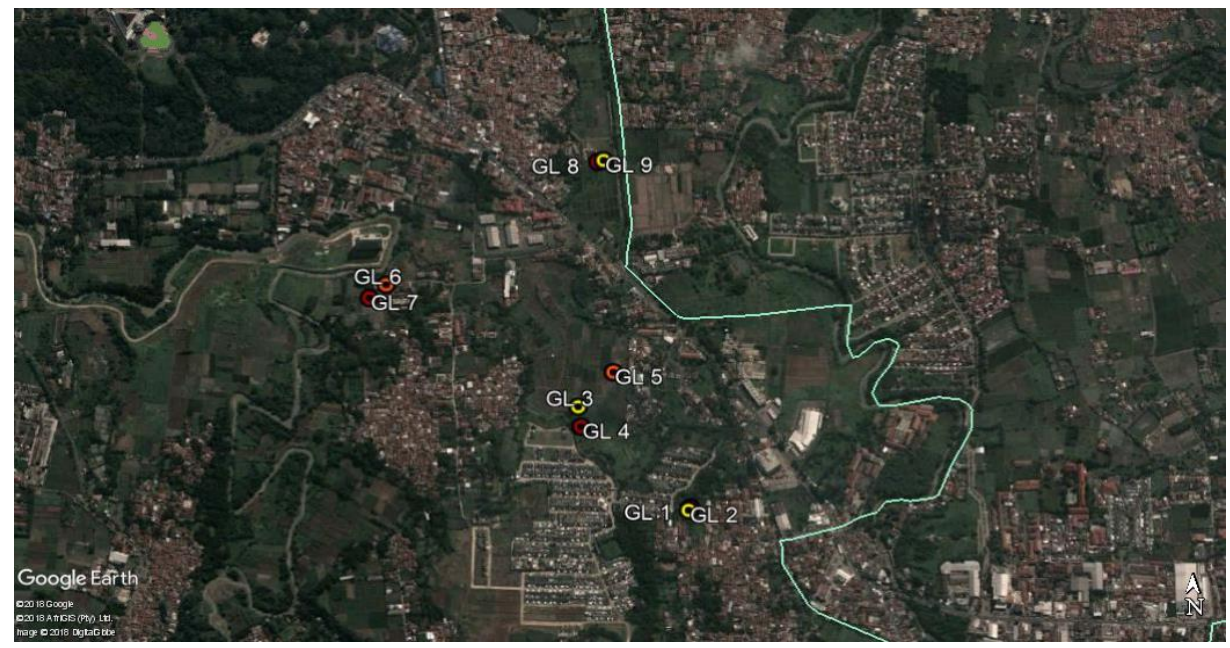

Gambar 2 Titik pengukuran geolistrik

Analisis data meliputi analisis penentuan faktor geometri untuk mendapatkan tahanan semu (apparent resitivity) yang nantinya akan diolah menggunakan software Progress version 3.0. Melalui pengolahan tersebut, maka akan didapatkan ketebalan akuifer di lokasi penyelidikan. Ketebalan akuifer dapat dilihat berdasarkan besarnya tahanan jenis setelah tahap pengolahan diatas.

Setelah tahanan jenis dihitung, maka dapat diketahui jenis tanah penyusun lapisan tersebut. Resistivitas semu (apparent resistivity) dirumuskan dengan persamaan berikut.

$\rho \mathrm{a}=K \frac{V}{I}$

Keterangan:

$\rho \mathrm{a}=$ apparent resistivity atau resistivitas semu $(\Omega \mathrm{m})$

$\mathrm{K} \quad$ = faktor geometri yang tergantung susunan elektroda/konfigurasi dimana $\mathrm{k}$ (m) adalah faktor geometri yang tergantung pada jenis konfigurasi jarak $\mathrm{AB} / 2$ dan $\mathrm{MN} / 2$.

$\mathrm{V}=$ beda potensial yang terukur (volt)

$\mathrm{I} \quad=$ tegangan arus (A)
Setelah nilai resistivitas dihitung, maka dapat diketahui lapisan batuan tersebut. Konfigurasi data geolistrik yang digunakan pada penelitian ini adalah konfigurasi Wenner-Schlumberger. Pengolahan data dilakukan dengan menggunakan Progress version 3.0. Hasil pengolahan akan disinkronkan dengan peta geologi dan hidrogeologi.

Nilai debit dari cadangan airtanah Kabupaten Bogor dapat diketahui dengan menggunakan persamaan darcy. Persamaan darcy digunakan dalam proses analisis data untuk menduga cadangan airtanah baik pada akuifer bebas maupun akuifer tertekan. Hukum darcy adalah persamaan yang mendefinisikan kemampuan suatu fluida mengalir melalui media berpori seperti batu. Hal ini bergantung pada prinsip bahwa jumlah aliran antara dua titik adalah berbanding lurus dengan perbedaan tekanan antara titik-titik dan kemampuan media melalui yang mengalir untuk menghambat arus.

Parameter yang digunakan untuk mengisi persamaan tersebut adalah konduktivitas hidrolik, gradien hidrolik serta luas penampang akuifer. Luas penampang akuifer dapat diperoleh dengan mengalikan nilai panjang penampang akuifer (W) dengan ketebalan akuifer (b). Gradien hidrolik dapat diperoleh dengan membagi beda 
kedalaman muka airtanah dengan panjang lintasan airtanah. Berdasarkan Todd dan Mays (2005) nilai debit dapat ditentukan dengan rumus pada persamaan (2).

$$
Q=K \times A \times \frac{\delta h}{\delta L}
$$

dimana :

$i=\frac{\delta \mathrm{h}}{\delta \mathrm{L}}$

$A=W \times b_{\text {akuifer }}$

sehingga,

$Q=\mathrm{K} \times W \times b_{\text {akuifer }} \times \frac{\delta \mathrm{h}}{\delta \mathrm{L}}$

dimana:

$Q \quad=$ Debit, $\mathrm{m}^{3} /$ hari

$A \quad=$ Luas penampang akuifer, $\mathrm{m}^{2}$

$W \quad=$ Panjang penampang akuifer, $\mathrm{m}$

$b_{\text {akuifer }}=$ ketebalan akuifer, $\mathrm{m}$

$K=$ Konduktivitas Hidrolik, $\mathrm{m} /$ hari

$i \quad=$ Gradien hidrolik

$\delta h=$ Beda kedalaman muka air tanah, $\mathrm{m}$

$\delta L=$ Panjang lintasan air tanah, $\mathrm{m}$

\section{HASIL DAN PEMBAHASAN}

\section{Keadaan Umum Daerah Penelitian}

Garis aliran (flownet) ditujukan untuk mengetahui arah pergerakan air tanah. Dengan mengetahui pergerakan air tanah, maka area penampang akuifer dari pergerakan air tanah tersebut dapat diketahui. Penampang akuifer $(W)$ adalah salah satu parameter yang diperlukan dalam pengukuran cadangan air tanah dengan menggunakan persamaan Darcy (Pers. 2). Data berupa koordinat dan elevasi merupakan data yang diperlukan untuk membuat flownet dengan bantuan software surfer version 10. Hasil pengolahan program disajikan pada Gambar 4 dan Gambar 5.

Kecamatan Dramaga terletak di wilayah Bogor Barat dengan luas wilayah
2.885 Ha. Pada peta geologi (Gambar 3), Kecamatan Dramaga terletak di formasi Batuan Gunungapi Gunung Salak (Tuf batuapung pasiran/Qvst; Lahar, breksitufan, dan lapili/Qvsb, serta Aliran lava/Qvsl). Daerah Kabupaten Bogor yang relatif terletak di utara Gunung Salak merupakan area depresi gunungapi yang terdiri atas batuan-batuan berumur Tersier dan Kuarter, yang secara fisiografi termasuk ke dalam Zona Bogor. Zona Bogor ini dicirikan oleh adanya antiklinorium depgan arah Barat-Timur. Struktur geologi yang berkembang merupakan hasil aktivitas periode tektonik Tersier yang tersingkap dengan baik, pada batuan berumur Tersier. Selain itupula terbentuk struktur-struktur Kuarter yang diakibatkan oleh aktivitas gunungapi Kuarter.

Pada peta hidrogeologi (Gambar 4), Daerah Kabupaten Bogor dapat dibagi rnenjadi beberapa kondisi keterdapatan air tanah dan tingkat produktivitas akuifer (Anonim, 1999). yang dikaitkan dengan beberapa faktor. Faktor tersebut antara lain akuifer dengan aliran rnelalui ruang antar butir, akuifer dengan aliran rnelalui celah dan ruang antar butir, akuifer dengan aliran rnelalui celahan dan rekahan, serta akuifer bercelah atau sarang. Hasil interpretasi terhadap datadata pengukuran geolistrik menunujukan bahwa interval nilai resistivitas litologi penyusun daerah penelitian cukup bervariasi, yaitu berkisar $6 \Omega \mathrm{m}$ sampai $2400 \Omega \mathrm{m}$. Litologi ditentukan dengan interpretasi: (1) Litologi dengan tahanan jenis 1-25 $\Omega \mathrm{m}$ diinterpretasikan sebagai lempung (2) Litologi dengan tahanan jenis 25-100 $\Omega \mathrm{m}$ diinterpretasikan sebagai pasir (3) Litologi dengan tahanan jenis 100-200 $\Omega \mathrm{m}$ diinterpretasikan sebagai batu pasir (4) Litologi dengan tahanan jenis 200$1000 \Omega \mathrm{m}$ diinterpretasikan sebagai tufa

(5) Litologi dengan tahanan jenis $\geq 1000$ $\Omega \mathrm{m}$ diinterpretasikan sebagai andesit. 


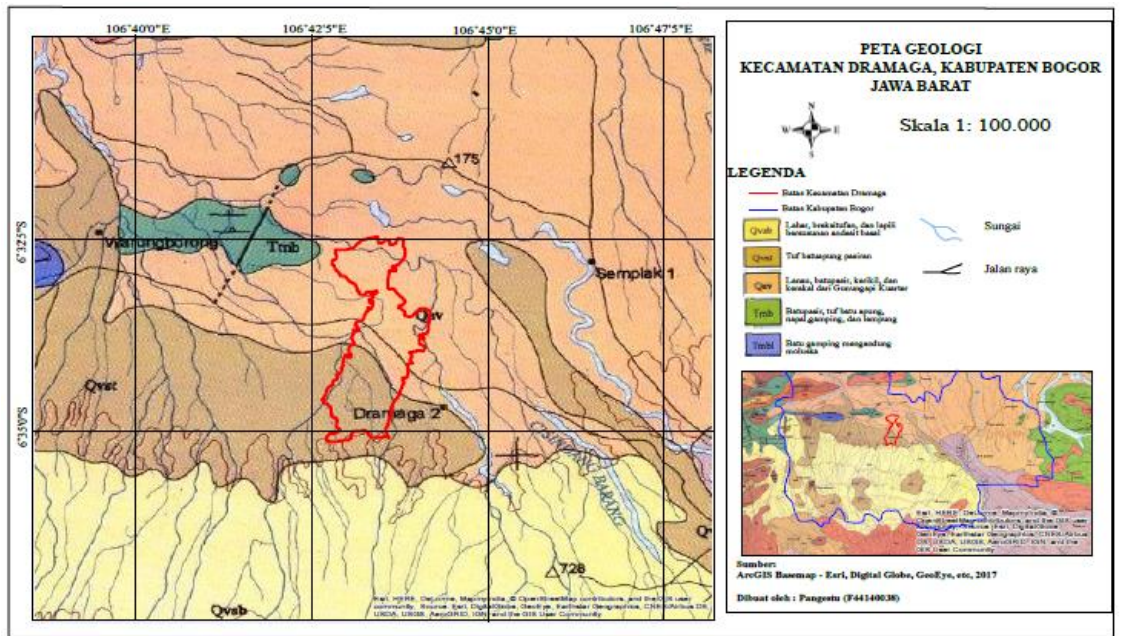

Gambar 3 Peta geologi Kecamatan Dramaga

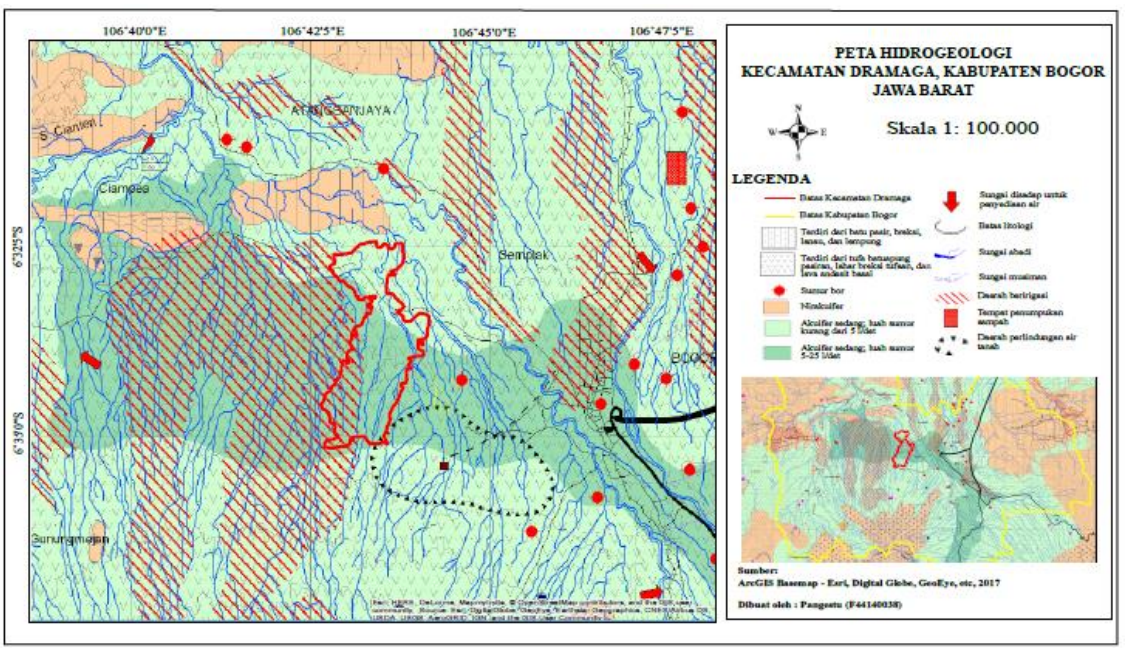

Gambar 4 Peta hidrogeologi Kecamatan Dramaga

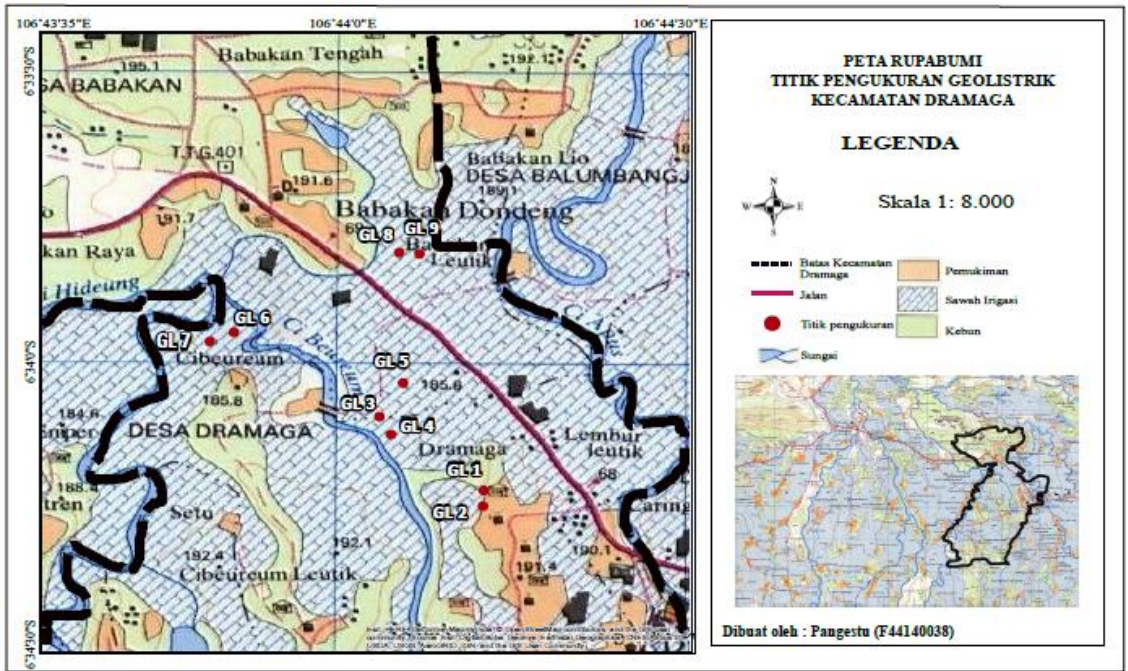

Gambar 5 Peta rupa bumi titik pengukuran geolistrik 


\section{Karakteristik Akuifer}

Pergerakan airtanah dapat diketahui dengan pola garis aliran airtanah. Garis aliran (flownet) adalah suatu garis sepanjang mana butir-butir air akan bergerak dari bagian hulu ke bagian hilir melalui media tanah yang tembus air (permeable). Dengan bantuan software surfer version 11, data koordinat titik lokasi penelitian dan elevasi permukaan tanah diolah menjadi peta flownet. Data yang diolah dengan software Microsoft Excel merupakan data kedalaman akuifer bebas dan akuifer tertekan berdasarkan interpretasi data borelog yang disajikan pada Tabel 1.

Berdasarkan Tabel 1 dapat diketahui nilai muka airtanah dan ketebalan pada akuifer bebas dan akuifer tertekan.

Tabel 1 Data kedalaman dan ketebalan akuifer bebas dan akuifer tertekan

\begin{tabular}{|c|c|c|c|c|c|c|}
\hline \multirow{3}{*}{ Titik } & \multicolumn{3}{|c|}{ Akuifer Bebas } & \multicolumn{3}{|c|}{ Akuifer Tertekan } \\
\hline & atas & bawah & \multirow{2}{*}{$\begin{array}{c}\text { ketebalan } \\
(\mathrm{m})\end{array}$} & \multirow{2}{*}{$\begin{array}{c}\text { atas } \\
(\mathrm{m} \text { bmt })\end{array}$} & \multirow{2}{*}{$\begin{array}{l}\text { bawah } \\
\text { (m bmt) }\end{array}$} & \multirow{2}{*}{$\begin{array}{c}\text { ketebalan } \\
(\mathrm{m})\end{array}$} \\
\hline & (m bmt) & (m bmt) & & & & \\
\hline GL 1 & 18,96 & 39,78 & 20,82 & 53,37 & 75 & 21,63 \\
\hline GL 2 & 22,49 & 34,01 & 11,52 & 59,66 & 75 & 15,34 \\
\hline GL 3 & 24,76 & 41,4 & 16,64 & 83,55 & 100 & 16,45 \\
\hline GL 4 & 22,3 & 40 & 17,7 & - & 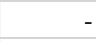 & \\
\hline GL 5 & 25,54 & 40 & 14,46 & - & - & \\
\hline GL 6 & 28,86 & 40 & 11,14 & - & - & \\
\hline GL 7 & 10,79 & 25,78 & 14,99 & 51,25 & 69,81 & 18,56 \\
\hline GL 8 & 2,83 & 12,36 & 9,53 & 69,74 & 86,62 & 16,88 \\
\hline GL 9 & 16,27 & 31,66 & 15,39 & - & - & \\
\hline \multicolumn{3}{|c|}{ Rata-rata } & 14,69 & & & 17,77 \\
\hline
\end{tabular}

Pada Gambar 6 dapat dilihat elevasi tertinggi berada pada bagian Selatan, sehingga pola pergerakan air cenderung terjadi dari GL 1 ke GL 8 dan GL 9, dari elevasi tinggi ke tempat dengan elevasi rendah.

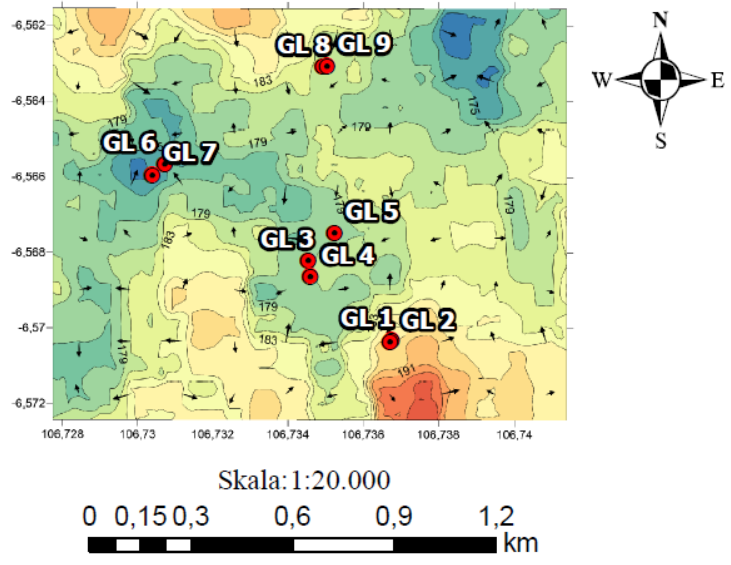

Gambar 6 Flownet lokasi penelitian

Interpretasi data geolistrik dilakukan untuk mengetahui penampang vertikal lapisan tanah. Penampang vertikal lapisan tanah sering disebut sebagai borelog atau diagram pagar. Borelog dapat mengukur ketebalan akuifer dan kedalaman akuifer di daerah pengukuran. Berdasarkan data kedalaman akuifer, ketebalan akuifer, dan data borelog, maka akuifer bebas dan akuifer tertekan dapat diketahui sebagai berikut:

1. Akuifer bebas (unconfined aquifer)

Akuifer bebas didominasi oleh pasir. Batas atas lapisan tersebut dapat ditemui pada kedalaman kisaran antara 2 28,86 meter bmt. Lapisan ketebalan akuifer berkisar 9-20 meter. Nilai konduktivitas hidrolik pada akuifer bebas bernilai $2.5 \mathrm{~m} /$ hari.

2. Akuifer tertekan (confined aquifer)

Akuifer didominasi oleh pasir dan batu pasir. Batas atas lapisan tersebut dapat ditemui pada kedalaman antara 51,25-83,55 meter bmt. Lapisan ketebalan akuifer berkisar 15-21 meter. Nilai konduktivitas hidrolik pada akuifer tertekan bernilai 2,04 meter/hari. Beberapa tempat tidak memiliki akuifer produktif sehingga tidak banyak dijumpai air tanah dalam. 


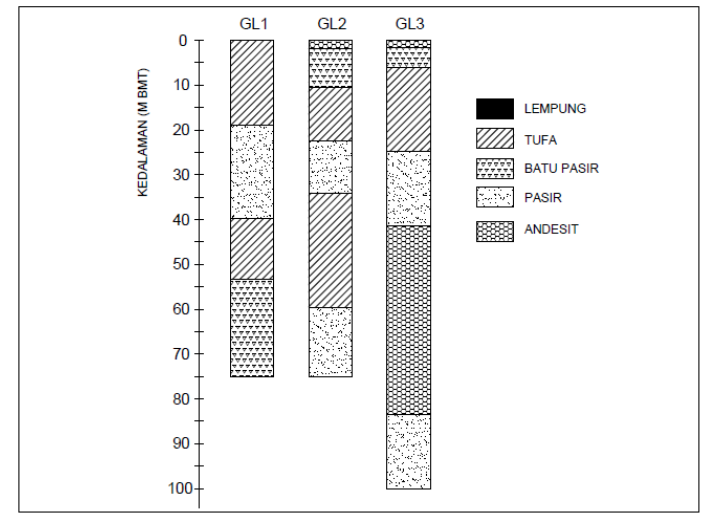

Gambar 6 Borelog pada Kecamatan Dramaga pada GL 1, GL 2, dan GL 3

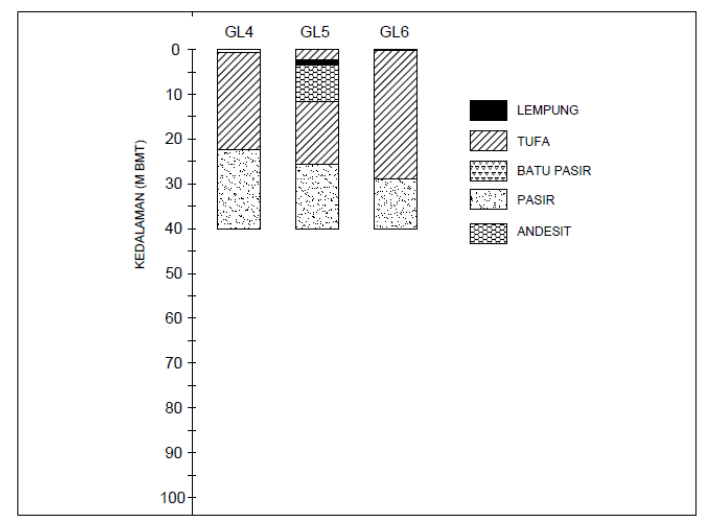

Gambar 7 Borelog pada Kecamatan Dramaga pada GL 4, GL 5, dan GL 6

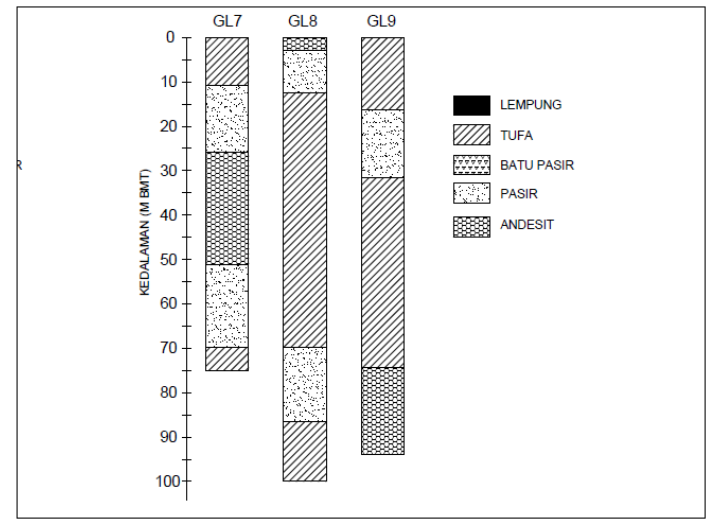

Gambar 8 Borelog pada Kecamatan Dramaga pada GL 7, GL 8, dan GL 9

\section{Prediksi Cadangan Air tanah}

Akuifer merupakan lapisan pembawa atau mengandung air karna terdapat cukup batuan yang mampu meloloskan air. Contoh krikil, pasir, batu gamping rekahan yang disebut dengan lapisan permeabel. Lampisan yang sulit dilalui airtanah disebut impermeabel, yakni lapisan kedap air dan lapisan kebal air (Hardiyatmo 2006) . Lapisan impermeabel terdiri dari dua jenis yakni lapisan batuan (rock) disebut lapisan kebal air (aquifuge), sedangkan lapisan yang sulit dilalui airtanah seperti lapisan lempung disebut lapisan kedap air (aquiclude) (Todd 1995).

Hasil dari data geolistrik yang diolah menggunakan software Progress version 3.0 didapatkan gambar borelog sebagai berikut yang disajikan pada Gambar 6, Gambar 7 dan Gambar 8. Tabel 2 merupakan nilai parameter persamaan Darcy. Ketebalan lapisan akuifer diperoleh dari hasil rata-rata kandungan lapisan akuifer di titik lokasi penelitian, sehingga dapat mewakili ketebalan akuifer yang ada. Untuk memperoleh nilai debit dengan menggunakan persamaan Darcy dibutuhkan nilai luas penampang akuifer, dimana luas akuifer diperoleh dengan mengalikan ketebalan lapisan akuifer dengan panjang penampang akuifer.

Tabel 2 Nilai parameter persamaan Darcy

\begin{tabular}{lccc}
\hline \multicolumn{1}{c}{ Parameter } & $\begin{array}{c}\text { Akuifer } \\
\text { Dangkal }\end{array}$ & $\begin{array}{c}\text { Akuifer } \\
\text { Dalam }\end{array}$ & Satuan \\
\hline $\begin{array}{l}\text { Konduktivitas hidrolik } \\
(K)\end{array}$ & 2,5 & 2,04 & $\mathrm{~m} / \mathrm{hari}$ \\
$\begin{array}{l}\text { Ketebalan lapisan }(b) \\
\text { Panjang penampang } \\
\text { akuifer }(W)\end{array}$ & 14,69 & 17,77 & $\mathrm{~m}$ \\
$\begin{array}{l}\text { Beda kedalaman muka } \\
\text { air tanah }(\delta h)\end{array}$ & 4,31 & 23,37 & $\mathrm{~m}$ \\
$\begin{array}{l}\text { Panjang lintasan air } \\
\text { tanah }(\delta L)\end{array}$ & 820 & 820 & $\mathrm{~m}$ \\
\hline
\end{tabular}

Tabel 3 merupakan pengukuran potensi cadangan air tanah dengan menggunakan persamaan Darcy, diperoleh nilai cadangan air tanah pada Kecamatan Dramaga untuk air tanah dangkal sebesar 241,29 $\mathrm{m}^{3} /$ detik dan air tanah dalam sebesar 1291,19 $\mathrm{m}^{3} /$ detik. Penggunaan air tanah secara berlebihan dapat menyebabkan berbagai dampak negatif. 
Tabel 3 Nilai prediksi cadangan air tanah

\begin{tabular}{ccc}
\hline $\begin{array}{c}\text { Jenis } \\
\text { Akuifer }\end{array}$ & $\begin{array}{c}\text { Prediksi } \\
\text { Potensi } \\
\text { Cadangan } \\
\text { Air Tanah } \\
\text { (m3/hari) }\end{array}$ & $\begin{array}{c}\text { Prediksi } \\
\text { Potensi } \\
\text { Cadangan } \\
\text { Air Tanah } \\
\text { (1/detik) }\end{array}$ \\
\hline $\begin{array}{c}\text { Akuifer } \\
\text { bebas }\end{array}$ & 241,29 & 2,79 \\
\hline $\begin{array}{c}\text { Akuifer } \\
\text { tertekan }\end{array}$ & 1291,19 & 14,94 \\
\hline
\end{tabular}

\section{KESIMPULAN}

Simpulan yang dapat diambil adalah (1) formasi geologi yang terdapat di Kecamatan Dramaga didominasi oleh Qa dan Qvst yang pada umumnya mengandung lempung, batupasir, tufa, andesit dan pasir.. (2) nilai rata-rata ketebalan akuifer bebas ialah 14,69 $\mathrm{m}$ dan ketebalan akuifer tertekan ialah 17,77 m. Nilai konduktivitas hidrolik rata-rata untuk akuifer bebas sebesar 2,5 $\mathrm{m} /$ hari dan akuifer tertekan sebesar 2,04 m/hari. (3) Prediksi cadangan air tanah dangkal dan dalam didapatkan mengunakan persamaan Darcy sebesar $241,29 \mathrm{~m}^{3} /$ hari atau 2,79 1/detik untuk akuifer bebas dan $1291,19 \mathrm{~m}^{3} /$ detik atau 14,94 $\mathrm{l} /$ detik untuk akuifer tertekan

\section{DAFTAR PUSTAKA}

Anonim. 1999. Pola pemanfaatan sumberdaya alam/air Kabupaten Bogor. BPPT dan Bappeda Kabupaten Dati II Bogor, Bogor.

Azwar H. 2009. Pemodelan lapisan airtanah dalam (akuifer) di Desa Telogorejo Kab. Demak berdasarkan data tahanan jenis [skripsi]. Jakarta (ID): Universitas Islam Negeri Syarif Hidayatullah.

Hardiyatmo HC. 2006. Penanganan Tanah Longsor dan Erosi. Yogyakarta (ID):
UGM Press.

Margat J, van der Gun J. 2013. Groundwater around the World: A Geographic Synopsis. Taylor \& Francis Group, New York (US) : CRC Press

Mori K. 2006. Hidrologi Untuk Pengairan (diterjemahan dari : Manual on Hydrology, penerjemah : L. Taulu). Jakarta (ID) : Pradyna Paramita

Naryanto HS. 2008. Potensi tanah di daerah Cikarang dan sekitarnya, Kabupaten Bekasi berdasarkan analisis pengukuran geolistrik. Jurnal Air Indonesia. 4(1): 38-49.

Pratitnyo P. 2008. Sistem akuifer dan cadangan airtanah di Propinsi Sulawesi Selatan. Jurnal Ilmiah MTG . 1(1):1-10.

Sudarto L. 2012. Prediksi Penurunan Muka Airtanah Akibat Pemompaan Di Daerah Jogonalan Klaten Jawa Tengah [skripsi]. Yogyakarta (ID): Universitas Pembangunan Negri Yogyakarta.

Suriawiria U.1996. Air dalam kehidupan dan lingkungan yang sehat. Bandung (ID) : PT Alumni

Todd DK. 1995. Groudwater Hydrology. Second Edition. Singapore (SG): John Wiley \& Sons, inc.

Todd DK, Mays LW. 2005. Groundwater Hydrology. 3th ed. Denver (US): John Wiley \& Sons, inc. 
$\underline{\text { JSIL } \quad \text { Pangestu dan Waspodo. : Prediksi Patensi Cadangan Air Tanah dengan Persamaan Darcy }}$ 